\title{
思考の研究（II）
}

乘京偪大心理學研觉空

外林大作

7. 循環と定位とつ關係

以上の實驗的結果を總括するならば，我々は次の樣に云らととが出來るであらう。国 ち，構造契機としての定位が不安定で，恰も試行錯誤法と呼ばれ得るかの樣な觀察的事 實を示与場合には，課题解决の目標は具體的に所要形態をむたない漠然としたもので女， つて，目標は機能的意味に於て，循環に陷つてるた。だから Lewin の如く，支万分類

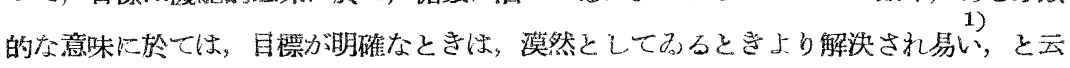
らことは，我々の概念的方式からも明確に演繹し得ることでする。

これを更に一般的に云らならば，や〉もすると思考的事實は嚴密な連續性に於て本質 的性格が見られるかの樣な感茎抱かせるかも知れないが，意識的連續性の切斷された飛 躍的過程に於て產出的思考過程は成立すんと見做さるべきである。郎ち，機能的循環は

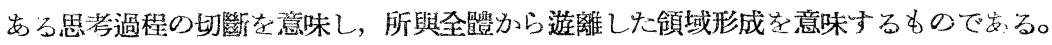
且つ，この領域は次元に於て所要性と完結的適性を持つてる,ないのである。(本行線證明 問題參照)

8. 比較の問題

比較はむる事態に於ては心理物理學的過程に就ての假設を要請する問題として從來考 察されて來た重要なすのでせり，我及のこの閣題の考究に於ても究局には導入しなけれ ばならないことは明であるが，こつで主として問題にし上うとするのは空間的圖式に於 ける比較の問題で女る。

課題：實驗に使用される材料は智能檢查のため使はれる重さ比較の簡單な課題です

1) Lewin, K: The Conceptual Representation and The Measuremeut of Psychological Forces, (1938) p. 69-70 然しこれは常にさらであるわけではな く，もつを正碓に云へば，目栖が猴環に陷つてみないときは云々とすべきである。

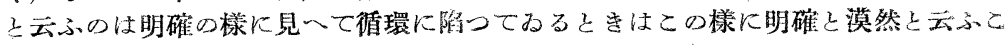
とを對照せしめることは船意味であるから。 


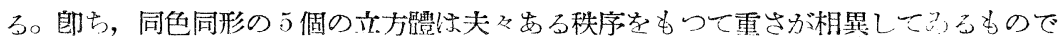

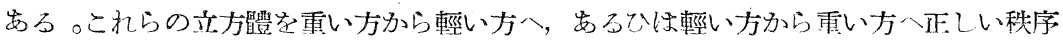

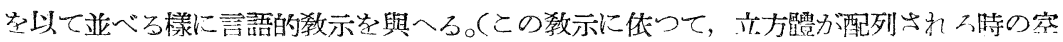
間的方向は左程重要な問題ではないのでこつでは無視しても良い。)

筫驗と問題 : この課題は一般には非常に容易であつて，一見殆ど所謂問題にならない 樣である。即ち，一般の智能水準に苃, 胃童に於いては殆ど問題と云ふに足りない課題 でせる。だから，教示に應じて，一度で正確な配列に列べられ，殆ど誤りまる配列は生 じない。からした課題に於いて夫くの立方體は如何にして比較せしめられろか，と云ふ と,そこには心理物理學的問題を提出する樣な行動を觀察することが出來るので女るが， この問題在今暫くの間除外視して，所謂精神薄弱兒と見做され得ろ樣な兒童に於ける行 動の觀察を主として問題としたい。

これらの兒竟に於いては殆どー一律に實驗者の㸚示に對して最初は無反應でをる。課題 に直面した時の困惑の表情も現孔ない。表情の失せた聜虛な相貌で女る。

先づ最初にこつで問題となるのは，これらの被驗兒童に於いては敎示の意味が理解さ

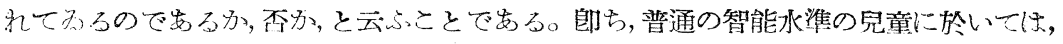

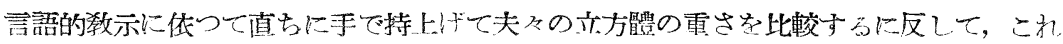
らの兒童に於いてはからてた行動が生起しない，と云心ことは如何なる原因に基くすの であららか,と云らことで岁る。この原因として容易に考へられることはら個の立方顝が

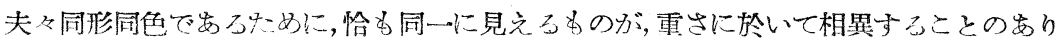
得ることが理解されず，かへつて被驗見童にとつては筫驗者の㸚示は無意味な言堞にな ろのか女知わない。若しこの理由に依つての文被驗兒童の反鷹のない相貌と課題にとり

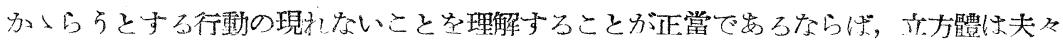
同色同形にもかいはらず重さは夫々ことなること趣解せ乙めるならば，からしな兒童 に於いても當然一般智能水準の兒童に於けるが如き比較配列の行動が唯繁されるはづで 安る。

然し乍ら，我从はこの理由在根據づける樣な事實を一般に觀察することぶ出來ない。郎

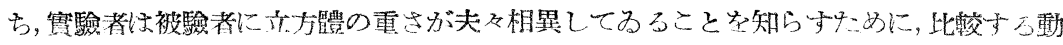

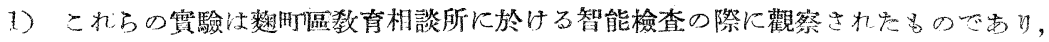
この考察の對象之ならた被驗兒童は國民學校一年生の女子ですり，これらの兒童沬 學校に於ては成績は最下位に屬し，教育の效果が開題にされてみるものですり，所 罚精济薄弱兒である。 
作を示し，この方があれよりは重いと云らことを敎示する。これに依つて被驗兒童は實 驗者の動作を模做して自ら立方體の輕重を知るかけでせる。文からした教示に作るのが 不適當である樣な際には實驗者は被驗兒童の手をとつて, 比較せしめ輕重を知らしめる。 前述の樣な理由に依つて精神薄弱兒に於いては比較の行動が生起しないものとするな らばからした呚示を與へた後には當然一般智能水準の兒童と同樣な比較の行動の生起 が觀察されるはづで女る。ところが，事實はこの函想に反してるる。からした敎示後に 觀察出來了主要な行動的性格は，第一に一般智能水準の兒童に於けるが如く行動は一般 に敏捷ではない。第二に5個の順序を比較する課題にもかつはらず，比較されるのは唯

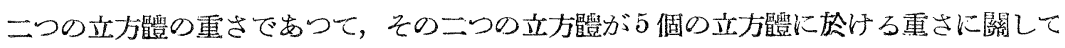
の秩序は考慮されない。たとへば，5個の立方體を重い順序に A， B , C , D , E とする と $\mathrm{A}, \mathrm{C} ; \mathrm{B}, \mathrm{E}$ と云ふ樣な個別的な比較は生起するのであるが，A と $\mathrm{B}$ ，岁るは $\mathrm{E}$ との關係は一般智能水蕉の兒童に於いて考慮されるに反して，これらの兒童に於いては 現れない。ナ゙から，この場合には $\mathrm{A}>\mathrm{C}, \mathrm{B}>\mathrm{E}$ であるから，たとへば， $\mathrm{A}, \mathrm{C}, \mathrm{B}, \mathrm{E}$ の順序に配列され，最後の D を何處に定位せしめるかと云ら課題過程は實際に D と 他の個別的立方椹が比較されると云ふことはなく，この例の樣に D は全體に於て輕い

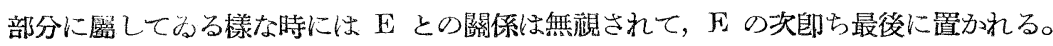

$\mathrm{A}, \mathrm{C} ； \mathrm{~B}, \mathrm{E}$ の樣に決定的に輕重が明なときには $\mathrm{A}<\mathrm{C}$ 或は $\mathrm{B}<\mathrm{E}$ と云ら樣な 訴 價は生起しないのであるが，たとへば $\mathrm{A}, と \mathrm{~B}$ の秩序を評價する際には $\mathrm{A}<\mathrm{B}$ と云ふ 樣な結果が生起することがある。然しこれは反覆によりてその評價の正否を決定するこ とが出來るし，この錯誤は一般智能水準の兒童に於いても噰及觀察される事實で女る。 反覆の効果に就いては既に述べをことがあるのでこつでは繰返へさないが，その論述に は不充分なところがある。

以上の樣な觀察的事實から明なことは，たとへ前述の理由があるとしても，さうした ものは大きな意味をもつてるっるのではなく，更に或る別の理由からして實驗賞初に於け るが如き無反應な行動が現れると見做すべきでせる。第二回目の敎示後の被驗兒童の行 動がのろいことと，比較は個別的でせつて全體との關聯が無視されてるるると云ら理由か らして，當然，被驗兒童は實驗者の第一回目の教示の意味が前述の樣な理由からして理

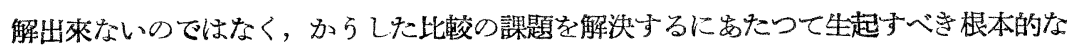

1)こっ時間は湘定されたわけではないが，觀察的に明である。

2)>印はこ〉では重さの輕重を示す。

3) 外林大作：思考心理學の根本問題，哲學雜誌 (56 卷 655 號) 


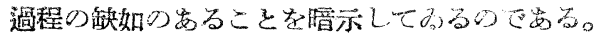

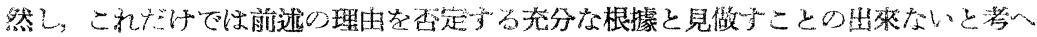

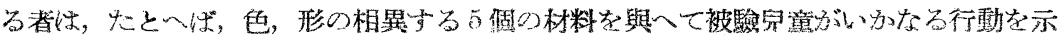

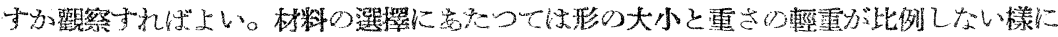

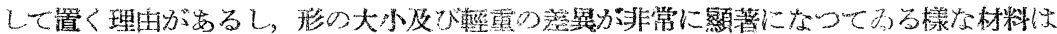

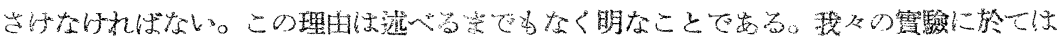

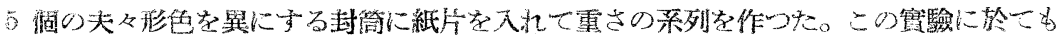

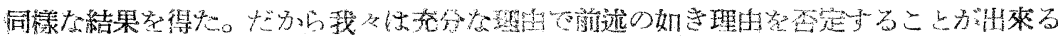
のた离。

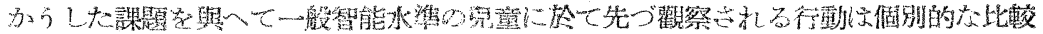

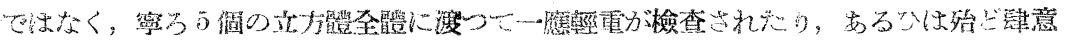

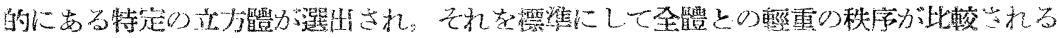

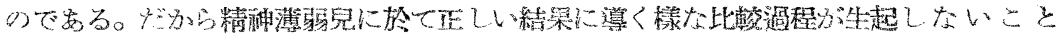

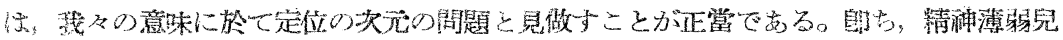

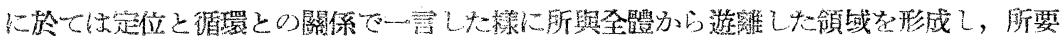

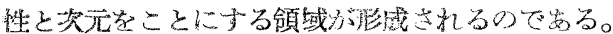

\section{8. 炏元心就て}

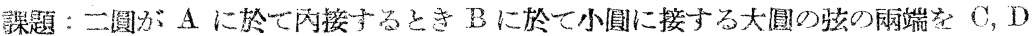

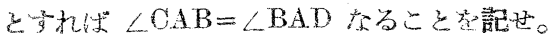

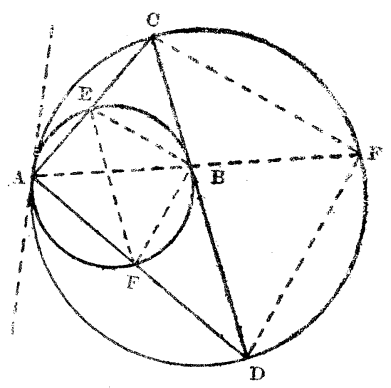

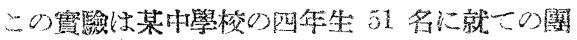

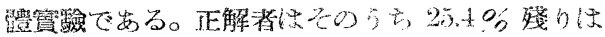

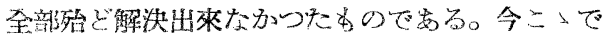

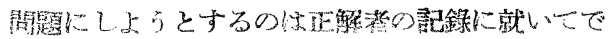

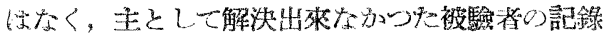

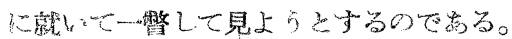

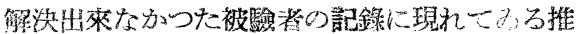

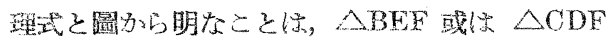

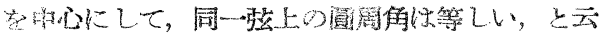

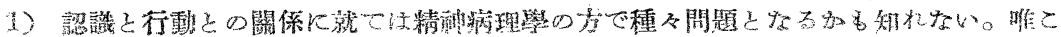

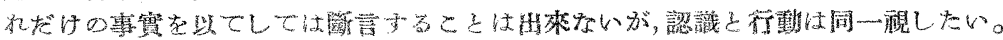

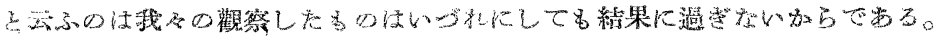




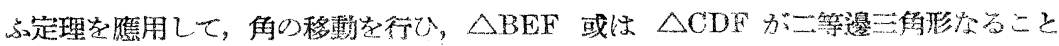
を證明せんとするものでるる。

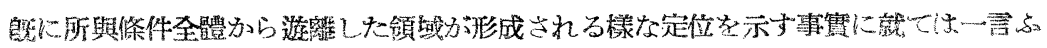

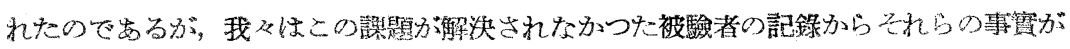
特殊完童に限られたものではないこと在明確に知ることが出來る。塊ち，譒題に於て目

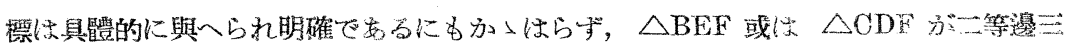
手形になることが必要なるためには $\angle \mathrm{CAB}=\angle \mathrm{BAD}$ が成立したければならないと原

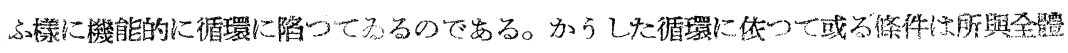

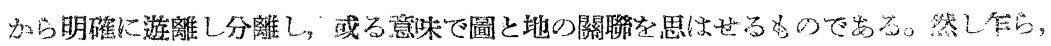

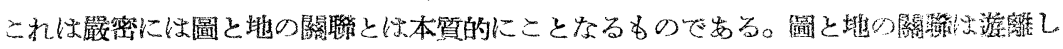

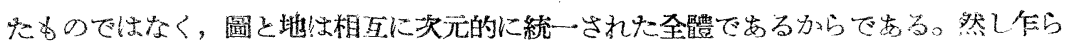

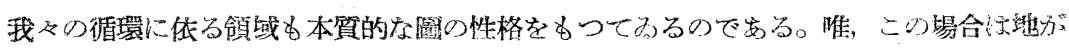

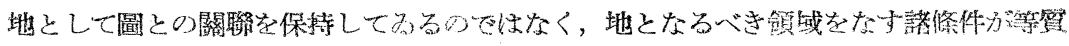

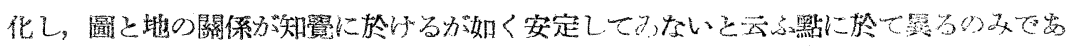

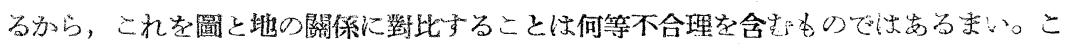

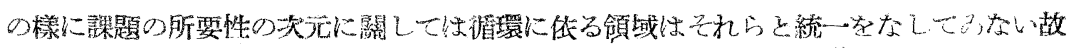

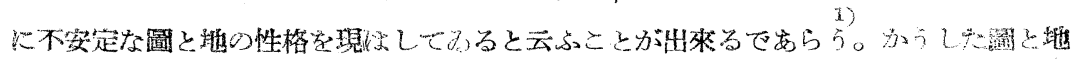
の性格から毁述の轉位の問題も解決し得るのである。

10. 轉 位

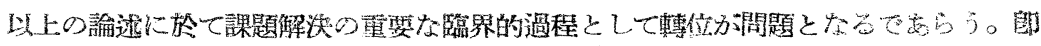

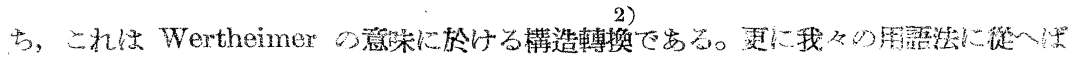

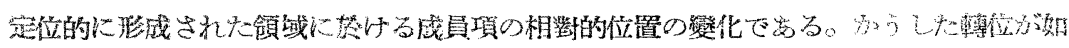

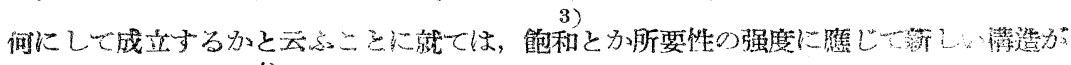

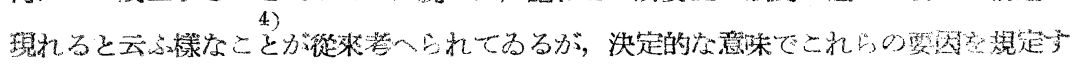

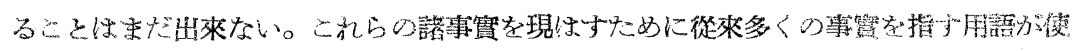

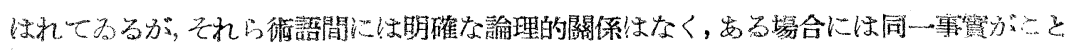

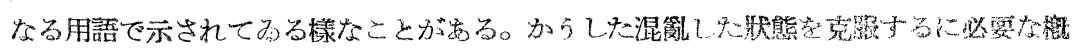
念は前述の意味に於ける圆と䍮との關係の樣に思はれる。(1941年10月8日原稿受附)

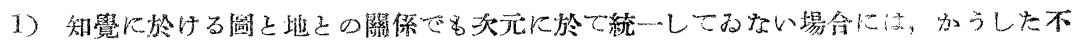

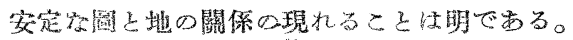

2) Wertheimer, M. : Ủber Schlubprozesse im produktiven Denken.1920.

3), 4) Vpl. Karsten. Duncker. 